\title{
ERRATUM
}

\section{Index of the Bacterial and Yeast Nomenclatural Changes Published in the International Journal of Systematic Bacteriology Since the 1980 Approved Lists of Bacterial Names (1 January 1980 to 1 January 1985)}

W. E. C. MOORE, ELIZABETH P. CATO, AND LILLIAN V. H. MOORE

Department of Anaerobic Microbiology, Virginia Polytechnic Institute and State University, Blacksburg, Virginia 24060

Volume 35, no. 3, p. 405, column 1: Vibrio alginolyticus subspecies iophagus is an illegitimate name and should be deleted from the list. Emod et al. (I. Emod, P. Soubigou, N. T. Tong, B. Keil, and C. Richard, Int. J. Syst. Bacteriol. 33:451-459, 1983) proposed "chemovar. iophagus" rather than "subspecies iophagus," as interpreted by us. "Chemovar." has no taxonomic standing according to the International Code of Nomenclature of Bacteria. 